\title{
Measuring Conduct in the Spanish Air Transport Industry
}

\section{Estimando la conducta de la industria del transporte aéreo en España}

Núm. 9 (2017), pp. 26-46

Gundelfinger Casar, Javier *

Coto-Millán, Pablo**

Recibido: noviembre, 2016

Aceptado: diciembre, 2017

JEL Clasif: C3, D4, L1, L9, M2, N7, R4

DOI: $10.5944 /$ reppp.9.2017.17600

Javier Gundelfinger CASAR: Técnico en Transporte Aéreo en el Gobierno de Cantabria (2006-Actualidad). Doctor en Economía por la Universidad de Cantabria. Líneas de Investigación: Economía Industrial y Economía del Transporte. E-mail: javier.gundelfinger@alumnos.unican.es

* Pablo Coto-Millán: Catedrático de Universidad de Fundamentos del Análisis Económico de la UC. Decano de la Facultad de Ciencias Económcias y Empresariales de la Universidad de Cantabria. Director del Máster y Experto Universitario en Comercio, Transportes y Comunicaciones Internacionales de la Universidad de Cantabria.. E-mail: cotop@unican.es 


\begin{abstract}
The purpose of this study is to analyze the domestic air transport industry in Spain. This work has focused on the segment of business and we present a theoretical model of oligopolistic competition which could be empirically tested through three equations: demand, market structure and price. We contribute to develop creativity and innovation with the elaboration of a data studying 113 over 96 fortnight periods (2011-2015) where analyses how clients react to both strategic changes carried out by airlines (frequencies, capacity, prices) and changes in socio-economic factors. The analysis is performed by applying the econometric technique of instrumental variables. We find that that frequency competition -Cournot- is more important than competition in prices -Bertrand-.
\end{abstract}

Key Words: Airlines; oligopolistic competition; market structure; vertical differentiation

\title{
Resumen
}

El objetivo de este estudio es analizar la industria del transporte aéreo en España. Este trabajo se ha centrado en el segmento de negocio y presentamos un modelo teórico de competencia oligopolística que puede ser empíricamente probado a través de tres ecuaciones: de demanda, de cuota de mercado y de precio. Contribuimos a desarrollar la creatividad y la innovación con la elaboración de una muestra que estudia 113 rutas durante 96 quincenas (2011-2015), donde se analiza cómo reaccionan los clientes tanto a los cambios estratégicos realizados por las líneas aéreas (frecuencias, capacidad, precios) como a cambios socio-económicos. El análisis se realiza aplicando la técnica econométrica de las variables instrumentales y los resultados muestran que la competencia en este mercado se produce a la Cournot.

Palabras clave: Aerolíneas; competencia oligopolística; estructura de mercado; diferenciación vertical 


\section{Introduction}

The liberalisation of air transport which took place in the European Union in the early nineties following the trend coming from the United States had positive effects for Spanish passengers allowing them to choose between more companies, more frequencies and much lower prices.

In addition to the aforementioned costumer benefit, it is necessary to know the airline's behavior following the liberalization process. After this process, further opening of markets will provoke a downward pressure on prices offered by the airlines to their consumers. This theoretical foundation -increased competition following liberalization and reduction of fares- is empirically assessed by Brander and Zhang (1993), who analysed it using a pooled cross-section and time-series data on 16 routes based at the hub airport of Chicago and operates by American Airlines and United Airlines in duopoly routes. The authors study, through regression analysis, if there is a competition following Cournot model or Bertrand model or if a formation of cartels occurs, concluding that there is a variable behavior (following the Green- Porter model) with an approach in periods of low prices -Cournot competition- and collusive agreements in higher rates stages.

The purpose of this paper is to collect the different reactions of agents involved in this industry and to determine whether a Cournot or a Bertrand competition is taking place through the study of 113 routes covering $97 \%$ of the active connections in Spain.

The original contribution of this paper to the existing literature lies on an increase of both the sample size -the number of routes analysed so far in the work of Marin (1995) is tripled and the sample used by Betancor and Gonzalez (2013) for our country is likewise increased- and also the time horizon, which goes from one week -Marin (1995) and Betancor and González (2013) - to 96 fortnights, introducing different variables, such as price per mile charged by airlines, travel time, aircraft capacity and frequencies offered for each flight, distance between each origin-destination pair, amount of landing taxes at each destination airport and evolution of oil prices and consumer price index, as well as several dummy variables, for each of the 113 routes.

A data panel was develop by observing the prices offered via their websites by the different airlines providing regular-commercial traffic services in the domestic market of our country, along with various other socio-economic variables, during the 96 fortnights of the study. The methodology followed a theoretical model of oligopolistic competition with vertical differentiation of products, which could be empirically tested through three equations: a demand equation, a market structure equation and a price equation. The vertical differentiation will be the result of the frequency of the service as a competition variable.

The structure of this paper is as follows: after the introduction, the second section reviews the literature on this field while the third section provides a theoretical basis for the hypotheses that are to be tested in the empirical analysis, specifying the equations to be estimated in the fourth chapter. The data and sample sources are detailed in section 5 , with section 6 focusing on the results obtained. Section 7 presents the conclusions that can be drawn from the study. 


\section{Review of the literature}

Betancor and González (2013) focused on the analysis of prices for airlines operating in Spain, concluding that an inverse relationship between the degree of competition and fares could be detected. This relationship is very clear in the case of routes where low cost airlines operate. Nuñez-Sánchez (2013) evaluates the pricing system for the Spanish port authorities during the period 1986-2005. Author estimates a system of equations. The estimation of demand functions for the use of port infrastructure enables us to calculate fee elasticities of demand. The sample consists of the 26 port authorities. After an estimation of demand function, author demonstrates that demands for port infrastructure are inelastic. Betancor and Viecens (2012) also studied domestic air routes claiming that a significant number of airlines compete in this market and, although there is a prominent group of low demand routes where services are provided under monopoly, in general, three or more air operators compete in almost a third of all routes. Similarly, Betancor and Viecens (2011) analysed the importance of airports from several points of view, as well as their main features in terms of traffic. Sainz-González et al. (2011) determine the impact on fares in the Spanish leisure market airlines. Authors use an empirical specification of a pricing and demand equation system. Authors use a data related to ticket price for quarterly periods 2006 and 2007. Data are based on round trip flights carried out in 29 domestic airports where the flights were made for leisure purposes. They found a duality of the Spanish airline tourist market, given that the behavior of airlines is more competitive for the case of peninsular routes. A plausible explanation would be the existence of more alternative modes of transport for these routes (e.g. car, high speed rail) which makes the travel demand more sensitive to prices. Fu and Zhang (2010) studied the relationship between the demand for air transport and economic growth, highly valuing the empirical relationship of air transport's multiplier effects on the economy. Moreover, Dobruszkes (2009) studied the degree of competition in air transport in Europe and concluded that competition in the air transport industry provides greater benefits to big cities and peripheral regions which receive major tourist inflows from large, northern cities in Western Europe. Njegovan (2006) evaluated the price elasticity in leisure travel in the UK, concluding that demand for air transport is moderately inelastic regarding ticket prices. Grosche et al. (2007) presented two gravity models to estimate the volume of air passengers between city pairs. Martinez (2003) also noted the impact of multimarket contact between airlines on the price level, finding evidence of the existence of collusive behaviour and detecting exhaustion effects after the liberalisation of the sector. Rey (2003) addressed the behaviour of airlines during the liberalisation process (1989-1997), attempting to determine the effects that this process had on the relative efficiency of airlines. The author did not find significant differences in efficiency among airlines over the time horizon studied. With regard to the pricing strategy, the study concludes that costs are a key factor determined by the average distances travelled and the occupation. Companies tend to cut costs by attempting to extend the distances travelled and increasing the size and occupation rates of their aircraft. The latter would be the clearest effects of the introduction of competition in the aviation market. Benitez (2000) identified the factors affecting demand for air services. In particular, the author refers to economic (income, prices), structural (population, distance, alternative modes of transportation, systems of established routes) and quality factors, but the analysis is theoretical and not empirical. 


\section{The theoretical model}

Our identification procedure takes as a reference the Marin (1995) study of the European air market, and the Fageda (2004) study of the domestic air market in Spain.

One of the central themes in the literature on air transport refers to the effects of price competition. As is well known, companies can compete on price, quantities and qualities.

The most common approach to analyse the effects of price competition is to use a price equation in which these depend on variables that approximate the cost and quality of service function, variables related to the characteristics of demand and factors approaching the market power of the dominant airlines.

We can distinguish two types of studies to address the effects of price competition.

There is a first type of studies within the so-called multiple equation approach (Graham, 1985, Dresner and Tretheway 1992) which, applied to the US market, uses observations in the concentration level of the route, and concludes that there is a positive correlation between the price level and the degree of concentration in the route. The second type of work is the so-called single equation approach (Borenstein, 1989, Evans and Kessides, 1993a). It also refers to observations of the US domestic airport market and concludes that it is their power, rather than the route, that explains the ability of the major airlines to charge higher prices than their competitors.

In the multiple equation approach, it is worth mentioning the work of Marin (1995), conducting studies for the air transport market in Spain. These authors went one step further than previous studies and incorporated a market share equation, taking the frequencies offered on each route and comparing them to the market average service on the route as one of the variables.

Specifically, these studies explicitly analyse the implications of competition on the market structure, rather than focusing solely on a price equation.

In addition, their empirical specification uses company-level variables on the route, in the equations for prices and market share, enabling them to capture possible intra-route heterogeneity. Moreover, vertical product differentiation is an important assumption of their theoretical and empirical formulation. This assumption can be considered realistic in the airline industry, where differences in quality between airlines arising from increased service frequency of dominant companies play an important role in competition. This is the reason why the empirical specification used in our study is based on this approach.

The empirical specification used in this study is based on a model of oligopolistic competition with vertical product differentiation, in other words, a service quality-based model, analysing the frequencies offered for each route. In this model, in the last phase of the decision process, each company $(i=1 \ldots . . N)$ produces a set of products with a perceived company quality, $q_{\mathrm{i}}$, compared to the average quality of all companies operating on the route, $k, q_{\mathrm{k}}$ and companies set prices according to the market competition regime. Each consumer chooses the product of the company that allows him/her to maximise the quality/price ratio, $q_{\mathrm{i}} / p_{\mathrm{i}}$ so the equilibrium condition for prices can be expressed as follows: 


$$
q_{\mathrm{i}} / p_{\mathrm{i}}=q_{\mathrm{j}} / p_{\mathrm{j}} \quad \text { for any company } i, j
$$

Given the condition of equation (1), the individual demand function can be expressed as follows:

$$
x_{\mathrm{ik}}=x_{\mathrm{ik}}\left(q_{\mathrm{ik}}, p_{\mathrm{ik}} q_{1 \mathrm{k}} / q_{\mathrm{ik}}, \ldots \ldots \ldots \ldots, p_{\mathrm{ik}} q_{\mathrm{N} \mathrm{I}}\right.
$$

So the amount sold by company $i, x_{\mathrm{ik}}$, when $N_{\mathrm{k}}$ companies operate on the route, depends on the perceived quality of the company on the route $k, q_{\mathrm{ik}}$, the prices of the company itself for the route $k, p_{\mathrm{ik}}$, the average quality of all companies operating on the route, $\left(q_{\mathrm{k}}\right)$ and other variables exogenous to the company (exogenous variables), called $e v_{\mathrm{ik}}$.

On the other hand, the market share of each company, $S M_{\mathrm{ik}}$, depends on the relative price and quality of each company with respect to the average value of the route, $k$, and other exogenous variables.

$$
S M_{\mathrm{ik}}=S M_{\mathrm{ik}}\left(p_{\mathrm{ik}} / p_{\mathrm{k}}, q_{\mathrm{ik}} / q_{\mathrm{k}}, e v_{\mathrm{ik}}\right)
$$

Expression (6) will provide the equation to estimate market share.

Assuming that companies compete following a Cournot model, the process of maximising profits provides the mark-up pricing equation on marginal costs:

$$
p_{\mathrm{ik}}=\Psi_{\mathrm{ik}}\left(q_{\mathrm{ik}} q_{\mathrm{k}}, N_{\mathrm{k}}\right) \frac{\partial \mathrm{C}_{\mathrm{ik}}}{\partial \mathrm{x}_{\mathrm{ik}}}
$$

Where the mark-up, $\Psi_{\mathrm{ik}}$ is a function of the relative perceived quality of each company with respect to the average market value $q_{\mathrm{ik}} / q_{\mathrm{k}}$, the number of companies operating in the market $N_{\mathrm{k}}$ and marginal costs $\frac{\partial \mathrm{C}_{\mathrm{ik}}}{\partial \mathrm{x}_{\mathrm{ik}}}$.

These costs will depend on determinant factors such as distance, capacity of the aircraft, frequency of service and/or occupation factor. 


\section{The empirical model}

All variables in empirical specifications shall be headed by the letter, meaning that the logarithms of the variables in question are used. In this sense, a total sample has been collected without considering the purpose of the trip and the equations for demand, prices and market share have been estimated. Regarding the variation by route, incorporating variables that refer to the characteristics of the route, such as distance, dummy for intermodal competition and dummy for operators, competition can help to manage these differences.

\subsection{Equation of demand by route and company}

According to equation (2) our empirical specification for the demand equation takes the following $\log$ form:

$$
L x_{\mathrm{ik}}=\delta_{1}+\alpha_{11} L i e v_{\mathrm{k}}+\alpha_{21} L q_{\mathrm{ik}}+\alpha_{31} L p_{\mathrm{ik}}+\alpha_{41} D N_{\mathrm{k}}+\varepsilon_{\mathrm{k}}
$$

Where the dependent variable is the number of passengers on each route, $L x_{\mathrm{ik}}$.

The explanatory variables in this equation are as follows:

$\boldsymbol{L i e v}_{\mathrm{k}}$ : Collects a proxy for the income exogenous variable approximated by the industrial production provincial index (IPI), as a proxy for economic activity. The IPI measures the monthly evolution of productive activity of industrial branches, that is, extraction, manufacturing and production industries as well as distribution of electricity, water and gas. A positive coefficient for this variable is expected.

$\boldsymbol{L q}_{\mathrm{ik}}$ : Number of daily frequencies offered by each of the airlines $i$ with respect to the market average in each route $k$. A positive coefficient for this variable is expected as an indication of the "quality" perceived by the consumer for such services.

$\boldsymbol{L p}_{\mathrm{ik}}$ : The price per mile offered by each airline $i$ for each route $k$. A negative sign is expected in the coefficient of this variable, assuming a normal demand curve.

$\boldsymbol{D N}_{\mathrm{k}}$ : This is a dummy variable representing the number of operators in each route $k$ that takes value 1 on routes with competition from other airlines and o otherwise. A positive sign is expected as increased competition implicitly means greater demand in the market. The extreme case would be a natural monopoly in which demand allows only one airline.

\subsection{Market share and company route equation}

According to equation (3), our empirical specification for the market share equation by company takes the following logarithmic form:

$$
L S M_{\mathrm{ik}}=\delta_{2}+\beta_{12} L p_{\mathrm{ik}}+\beta_{22} L q_{\mathrm{ik}}+\beta_{32} D N_{\mathrm{k}}+\varepsilon_{\mathrm{k}}
$$

Where the dependent variable is the market share of each airline $i$ on route $k$ in terms of number of passengers carried by each company out of the total, $\boldsymbol{L S}_{\mathrm{ik}}$. 
The explanatory variables in this equation are:

$\boldsymbol{L p}_{\mathrm{ik}}$ :The price per mile offered by each airline $i$ for each route $k$. A negative sign is expected in the coefficient of this variable, assuming a normal demand curve.

$\boldsymbol{L} \boldsymbol{q}_{\mathrm{ik}}:$ Number of daily frequencies offered by each of the airlines $i$ with respect to the market average in each route $k$. A negative sign is expected in the coefficient of this variable as increase of capacity.

$\boldsymbol{D} \boldsymbol{N}_{\mathrm{k}}$ : This is a dummy variable representing the number of operators in each route $k$ that takes the value 1 on routes with competition from other airlines and $o$ otherwise. A negative sign is expected as increased competition implicitly means a lower market share.

\subsection{Pricing equation by company and route}

The specification of the price equation, based on (4), is as follows:

$$
L p_{\mathrm{ik}}=\delta_{3}+\theta_{13} L d_{\mathrm{k}}+\theta_{23} L c_{\mathrm{ik}}+\theta_{33} D N_{\mathrm{k}}+\theta_{43} L q_{\mathrm{ik}}+\varepsilon_{\mathrm{k}}
$$

Where the dependent variable is the price per mile charged by each company $i$ in each route $k, L p_{\mathrm{ik}}$.

The explanatory variables included in the equation to approximate the marginal costs are as follows:

$\boldsymbol{L d}_{\mathrm{k}}$ : The distance between origin and destination of the route $k$. A negative sign is expected in the coefficient of the distance variable, since the costs per mile decrease with distance so a transfer of such reductions to prices can be expected.

$\boldsymbol{L c}_{\mathrm{ik}}$ : The average capacity of the aircraft used by each company $i$ in each route $k$. The coefficient of this variable is undefined, since the larger the aircraft, the lower the costs and the higher the quality perceived by the consumer.

$\boldsymbol{D N}_{\mathrm{k}}$ : This is a dummy variable representing the number of operators (operators exogenous variable) on each route $k$; it is set to 1 on routes with competition from other airlines and o otherwise. A negative sign is expected as increased competition implicitly means less market power (and therefore lower market share) to raise the price.

$\boldsymbol{L} \boldsymbol{q}_{\mathrm{ik}}:$ Number of daily flights offered by each of the airlines $i$ with respect to the market average in each route $k$. A negative sign is expected in the coefficient of this variable due to scale economies.

\section{Data sources and sample}

In the Annex, Table offer the descriptive statistics of the main variables used in this research.

The sample used in the empirical analysis includes 96 observations on a fortnightly basis from March 2011 to February 2015 for the Spanish domestic market of regular flights, including 113 routes collected in Table 2 of the Annex. 
The information on the total passengers carried by each airline $i$ in each route $k, x_{\mathrm{ik}}$, and on the national total passengers with origin in each airport $x n_{\mathrm{k}}$ has been obtained from the statistics published both by AENA and the Ministry of Public Works. Information regarding prices per mile $p_{\text {ik }}$ for each company on each route, flight time on the route $k$, $t_{\mathrm{k}}$, capacity of the aircraft used by each operator $i$ on each route $k, c_{\mathrm{ik}}$ and frequency of the flights of company $i$ compared to the average of the market $q_{\mathrm{ik}}$ in route $k$, has been obtained through the websites of each airline and AENA. The methodology to track prices has been to make a reservation on the first and second Wednesday of each month to fly on the third and fourth Wednesday of that month (booking 15 days in advance in each fortnight) through the website of each airline operating in each route, and selecting a return ticket on the day, providing the destination was reached before $10 \mathrm{am}$ and departure from the destination airport was always after $16 \mathrm{~h}$.

The variable distance of route $k, d_{\mathrm{k}}$ refers to the distance in miles between the origin and destination of each route, measured through an orthrodromic route, that is, the shortest distance between two points on the surface of the Earth.

Data on the market share $S M_{\mathrm{ik}}$ of each company on each route and the first operator $S M 1_{\mathrm{ik}}$ at the airport of origin of each route have been obtained from the financial reports of the airlines analysed.

The income exogenous variable $\left(i e v_{k}\right)$ is approximated by the provincial value of the Industrial Production Index IPI offered by the Spanish National Statistics Institute (INE).

The Consumption Price Provincial Index $i p c_{\mathrm{k}}$ corresponds to that offered by the INE. The Hotel Price Provincial Index $i p h_{\mathrm{k}}$ and the sum of the provincial population in each origin-destination route $p o b_{\mathrm{k}}$ were obtained from the INE.

The amount of landing taxes at each destination airport, $\operatorname{tax}_{\mathrm{k}}$, has been obtained through AENA, while the price of oil, brent fuel, has been compiled through the economic website www.cincodias.com.

Moreover, we have included the following seven dummy variables: 1) Existence or absence of alternative direct transport, -alternative Transport- $\left(\right.$ Dat $\left._{\mathrm{k}}\right)$. This variable is set to 1 when direct routing exists and o otherwise. 2) Hours of alternative transportation, -alternative transport hours-( Dath $\left._{\mathrm{k}}\right)$, which takes the value 1 if the alternative mode of transportation (bus, train, fast ferry in the case of the Balearic Islands) takes less than 210 minutes, since in such case it is considered that there is a competitive means of alternative transportation, and takes the value o otherwise. To calculate this time we studied the information on transport times on the websites of each of the operators of each alternative mode of transportation. 3) Number of operators -operators exogenous variable- $\left(D N_{k}\right)$, which takes the value 1 on routes with more than one operator and $o$ otherwise. 4) Existence of a hub airport, -hub airport- $\left(D h a_{\mathrm{k}}\right)$, which takes the value 1 for airports with international flights operations and o otherwise. 5) Existence of routes operated by high-speed rail lines, AVE -high-speed train $\left(\right.$ Dhst $\left._{\mathrm{k}}\right)$, which takes the value 1 in routes where such transport exists and is set to o otherwise. 6) Presence of Ryanair at the origin airport, -Ryanair existence- $\left(\right.$ Drye $\left._{\mathrm{k}}\right)$, which takes the value 1 if yes and o otherwise. 7) Finally, the possibility that the origin airport maintains agreements to promote tourism -Tourist promotion agreement- $\left(D t p a_{\mathrm{k}}\right)$, taking as reference the report of the National Competition Commission of Spain, which takes the value 1 when these arrangements exist and o otherwise. 
We have included the existence of a hub airport dummy and the Ryanair presence in every route dummy according to Tretheway and Kincaid (2005) who review the literature about the economic effect of a market structure (Borenstein, 1990) on air fares following deregulation of the U.S. airline market. The authors concluding that regardless of market structure, the presence of a Low Cost Carriers (LCC) has a dramatic and permanent impact of fares in the market (Lee and Luengo-Prada, 2005).

\section{Estimation and Results}

In order to avoid endogeneity problems, the technique of estimation by instrumental variables (IV), Angrist and Krueger (2001) has been applied. This method allows a consistent estimate when variables are suspected to be endogenous and is based on the choice of a variable (instrument) that does not belong to the model initially estimated, is correlated with the explanatory variable (endogenous) and is not correlated with the error term of the estimated equation.

In addition, for the choice of instrumental variables to be a valid instrument to address the problem of endogeneity, these must be credible from an economic point of view and the equation to estimate must be properly identified (Murray, 2006). According to Angrist and Krueger (2001), estimation by instrumental variables not only corrects the endogeneity problem, but its application may avoid a problem of measurement error in the endogenous variable, which would lead to an attenuation bias in the estimates by Ordinary Least Squares, (OLS).

There is an important aspect among the measures implemented to solve the problem of endogeneity, which is to ensure that the chosen variable for correction is not a weak instrument. To avoid this, the F-statistic of Wald Cragg-Donald is reviewed. If the critical value is greater than 10, the instrument is not considered weak (Stock and Yogo, 2005). This fact certifies that the variable considered as instrument predicts the endogenous variable correctly.

In the event that the instrument is weak, the slight presence of correlation between the instrument and the error term in the original equation can cause major inconsistencies in the coefficients computed. This problem arises at the time when the instrument is very weakly correlated with the regressor (endogenous) or its size is very large (Angrist and Krueger, 2001). Within the referred technique of estimation by instrumental variables, the least squares method is implemented in two stages (2SLS), Theil (1961) and Basmann (1957); as well as the Generalized Method of Moments (GMM), Hansen (1982).

After identifying the problem of endogeneity and having used $\mathrm{MC}_{2} \mathrm{E}$, it is possible to use an alternative estimation method that allows for a greater degree of confidence, which is the Generalized Method of Moments (GMM). This method is an estimator of instrumental variables, which ensures that the estimated parameters are consistent under the existence of conditions that validate the efficiency with which the available information is used. Furthermore, this method does not require the assumption of normality and allows estimates to a greater level of confidence, because it uses the orthogonality conditions or moments for a more efficient estimate. 
That is, this method provides consistent estimators for the multiple regression model and confirms the independence of the exogenous variables under study.

Table 3 shows the results of each of the two estimates (least squares in two steps by instrumental variables and Generalized method of moments) for the demand equation. Table 4 presents the results for each of the two estimates (two-stage least squares with instrumental variables and Generalized method of moments) for the market share equation. Table 5 presents the results for each of the two estimates (least squares in two stages using instrumental variables and Generalized method of moments) for the price equation.

The regressions were calculated using the econometric software Gretl 1.47.

Going to the data analysed, in Table 3 we can see how the explanatory variables have the expected sign and are significant at $1 \%$. Thus, it is possible to show that income, frequency, number of operators and prices are important determinants in the demand for business air transport in Spain. The elasticity of demand with respect to the approximated income by the industrial production index is 3.66 and the elasticity of demand with respect to the frequency is 2.13 , while the elasticity of demand on the number of operators is 0.65 . Finally, the price elasticity of demand is set to -0.60. Therefore, it is clear that the elasticity of demand with respect to frequency is much higher than the demand price elasticity ( 2.13 vs. -0.60), so this industry is more sensitive to competition in frequencies than in prices.

Analysing the market share equation in Table 4 we can see how the explanatory variables have the expected sign. Thus, it is shown that the prices, frecuencies and number of operators are important determinants in the market share of business air transport in Spain. The coefficient of the variable elasticity of the market share to price is positive and significant with a value of 0.20 . That is, an increase in prices would imply an increase in market share. This sign is opposite to the expected value and can be explained due to the higher number of routes under the monopoly operation. The rate variable is significant and negative (-0.23). Therefore, an increase in the frequencies offered produces a reduction in market share. That is, the greater the frequency on a route, the more competition and less market share. The elasticity of the market share to the number of operators is significant and has a negative sign (-0.56). This means that if more than one operator competes on a route, the market share drops to $56 \%$ of market share.

Table 5 shows the results for the price equation. All variables have the expected sign. The coefficient of the distance variable has the expected sign (-0.09). Greater distances entail lower prices, although this interpretation should be taken with caution, because the variable is only significant at $10 \%$. The coefficient of the variable "average aircraft size", measured by available seat capacity per aircraft on each route, is significant at 1 $\%$ and has a negative value (-0.63). That is, the more efficient the aircraft, the lower the prices. The price elasticity to the number of operators is significant and has a negative value (-1.13). This means that if more than one operator competes in a route, the price per mile drops by $113 \%$. This result is similar to that reported by Betancor et al. (2013).

Finally, the ratio of the daily frequency variable with respect to the market average is significant at $1 \%$ and takes the value (-0.38); that allow us to ensure that there is an oligopoly market structure. That is, the policy of pricing in the pricing in the airline industry in Spain is carried out by a few companies. 
On the other hand the results of table 6 show rates of Entropy, Herfindahl and Lerner exist for concluding oligopolistic market structure. In the airline industry in Spain are a few companies that perform pricing policy.

\section{Conclusions}

In the study by Marin (1995) analysing the inter-European market, the results lead to the conclusion that price competition -Bertrand- is more important than competition in frequency (quality) -Cournot- for the leisure air segment because in the demand equation estimated, price elasticity is -1.71 , not significant for the frequency variable. In the work of Coto-Millán (2003), estimates for the pre-liberalisation period in Spain are presented without distinguishing between the leisure and business segments, with a demand price elasticity of -1.26 and an income elasticity of 1.32 . This has been the situation in eighties and nineties in Spain and in the inter-European market. In this research the demand price elasticity is -0.60 and the estimated demand and frequency elasticity is 2.13. Demand and price elasticities are not very different. However, the demand frequency elasticity in the last study was twice as high as in the previous one.

In this research for the recent period 2011-2015, the results shown in the demand equation confirm this because the elasticity of demand regarding frequencies (2.13) has proved to be much higher than the price elasticity of demand (-0.60) showing that this industry competes more in frequencies (quality) than in prices. The above results show the progression from only price competition in the nineties, before liberalisation, to a balanced price and frequency competition, to an increased competition in frequencies compared to price in recent years.

It seems logical that, in a commuter passenger market catering to round-trip passengers with a highly valued concept of time, airlines compete via frequencies (quality) to attract passengers. That is, in this market, companies are competing to offer higher quality products (via a higher frequency of service) than their rivals on most routes in which more than one operator offers their services.

In this paper, the estimation of the price equation obtains similar results as Betancor and González (2013) in the sense that an inverse relationship is detected between the degree of competition (measured by $D N_{k}$ ) and ticket price (price per ticket/mile). Moreover the results show rates of Entropy, Herfindahl and Lerner exist for concluding oligopolistic market structure. In the airline industry in Spain are a few companies that perform pricing policy.

In conclusion, we can say that the maintenance or improvement of effective competition in this segment of the aviation industry in Spain recommends greater competition in the prices offered by airlines, since competition in terms of frequencies (quality) is more intense (about three times). 


\section{References}

Angrist, J. D., \& Krueger, A.B. (2001). Instrumental Variables and the Search for Identification: From Supply and Demand to Natural Experiments. Journal of Economic Perspectives, 15(4), 69-85.

Basmann, R. L. (1957). A Generalized Classical Method of Linear Estimation of Coefficients in a Structural Equation, Econometrica, 25, 77-83.

Benítez Rochel, J.J. (2000). Factores determinantes de la demanda de transporte aéreo y modelos de previsión. Boletín económico de ICE, Información Comercial Española, ISSN 0214-8307, 2652, 41-48.

Betancor, O., Gallego, A. \& Gonzalez, M.J. (2013). Las tarifas en el mercado español de transporte aéreo. Observatorio de Transporte Aéreo Fedea.

Betancor, O. \& Viecens, M. F. (2012). La competencia en el mercado español de transporte aéreo. Observatorio de Transporte Aéreo Fedea.

Betancor, O. \& Viecens, M. F. (2011). Una taxonomía de los aeropuertos españoles. Observatorio de Transporte Aéreo Fedea.

Borenstein, S. (1989). Hubs and high fares: Dominance and market power in the U.S. airline industry. Journal of Economics, 20, 344-65.

Borenstein, S. (1990). Airline mergers, airport dominance, and market power. The American Economic Review, 80(2), 400-404.

Brander, J. \& Zhang, A. (1993). Dynamic oligopoly behaviour in the airline industry. International Journal of Industrial Organization, 11, 407-435.

Coto-Millán, P. (2003). Utility and Production. Theory and Application. Second edition. Physica-Verlag a Springer-Verlag Company.

Dobruszkes, F. (2009). Does liberalisation of air transport imply increasing competition? Lessons from the European case. Transport Policy, 16(1), 29-39.

Dresner, M. \& Tretheway, M.W. (1992). Modelling and testing the effect of market structure on price; the case of International Air transport. Journal of Transport and Economic Policy, 26(2), 171-183.

EUROCONTROL. (2015). Annual Report 2015.

Evans, W.N. \& Kessides, I. (1993a). Localized market power in the U.S. airline industry. The Review of Economics and Statistics, 75(1), 66-75.

Fu, X., Hong, O. T. \& Zhang, A. (2010). Air transport liberalization and its impacts on airline competition and air passenger traffic. Transportation Journal, 49(4), 24.

Graham, D.R., Kaplan, D.P, \& Sibley, D.S. (1983). Efficiency and competition in the airline industry. Bell Journal of Economics, 14, 118-138. 
Grosche, T., Rothlauf, F. \& Heinzl, A. (2007). Gravity models for airline passenger volume estimation. Journal of Air Transport Management, 13, 175-183.

Hansen, L. P. (1982). Large Sample Properties of Generalized Method of Moments Estimators, Econometrica, 50, 1029-1054.

Lee, D. \& Luengo-Prado, M.J. (2005). The Impact of Passenger Mix on Reported "Hub Premiums" in the U.S. Airline Industry. Southern Economic Journal, Southern Economic Association, 72(2), 372-394.

Marin, P. (1995). Competition in European Aviation: Pricing Policy and Market Structure. Journal of Industrial Economics, 43, 141-160.

Martínez, C. (2003). Análisis del sector aéreo europeo: Modelización de la demanda y análisis del contacto multimercado entre compañías. From CEMFI No. 0306.

Murray, M. P. (2006). Avoiding Invalid Instruments and Coping with Weak Instruments. Journal of Economic Perspectives, 20(4), 111-132.

Njegovan, N. (2006). Elasticities of demand for leisure air travel: A system modelling approach. Journal of Air Transport Management, 12(1), 33-39.

Nuñez-Sánchez, R. (2013). Marginal Costs, Price Elasticities of Demand, and Second-best Pricing in a Multiproduct Industry: An Application for Spanish Port Infrastructure. Journal of Transport Economics and Policy, 47(3), 349-369.

Rey, B. (2003). Estructura de mercado y eficiencia empresarial en el transporte aéreo. ICE número 808, 189-200.

Sainz-González, R., Núñez-Sánchez, R. \& Coto-Millán, P. (2011). The impact of airport fees on fares for the leisure air travel market: The case of Spain. Journal of Air Transport Management, 7(3), 158-162.

Sargan, J.D. (1958). The Estimation of Economic Relationships Using Instrumental Variables. Econometrica, 26, 393-415

Stock, J. \& Yogo, M. (2005). Testing for Weak Instruments in Linear IV Regression. Ch. 5 in J.H. Stock and D.W.K. Andrews (eds), Identification and Inference for Econometric Models: Essays in Honour of Thomas J. Rothenberg, Cambridge University Press.

Theil, H. (1961). Economic Forecasts and Policy. 2nd ed. Amsterdam: North-Holland.

Tretheway, M. \& Kincaid, I. (2005). The effect of market structure on airline prices: A review of empirical results. Journal of Air Law and Commerce, 70, 467-497. 


\section{Annex tables}

Table I. Descriptive statistics. Source: Own elaboration.

\begin{tabular}{|c|c|c|c|c|c|c|}
\hline Variable & Mean & Median & Mínimum & Máximum & Std. Dev. & C.V. \\
\hline$L x_{i k}$ & 104.514 & 104.689 & 460.517 & 125.927 & 109.659 & 0.104923 \\
\hline$L x_{n k}$ & 126.949 & 129.564 & 606.146 & 143.186 & 135.926 & $0.10707 \mid$ \\
\hline$L p_{i k}$ & -0.512544 & -0.450069 & -305.130 & $|64.58|$ & 0.818686 & 159.730 \\
\hline$L t_{k}$ & 423.454 & 417.439 & 355.535 & 539.363 & 0.340447 & 0.0803978 \\
\hline$L c_{i k}$ & 489.353 & 519.296 & 391.202 & 524.175 & 0.444849 & 0.0909055 \\
\hline$L q_{i k}$ & -0.14362 & -0.25722 & -14.130 & 17.352 & 0.50636 & 35.258 \\
\hline$L d_{k}$ & 550.360 & 552.545 & 426.268 & 686.380 & $0.5687 \mid 7$ & 0.103335 \\
\hline$L S M_{i k}$ & -0.518146 & -0.510826 & -299.573 & 0.00000 & 0.546323 & 105.438 \\
\hline $\operatorname{Liev}_{k}$ & 450.377 & 450.910 & 405.340 & 477.200 & 0.114443 & 0.0254104 \\
\hline$L i p c_{k}$ & 463.207 & 463.603 & 459.139 & 466.240 & 0.0167499 & 0.00361608 \\
\hline$L i p h_{k}$ & 447.988 & 448.864 & 428.027 & 472.827 & 0.0922993 & 0.0206031 \\
\hline $\operatorname{Lpob}_{k}$ & I 47.248 & 147.568 & 113.062 & 156.752 & 0.905913 & 0.0615230 \\
\hline $\operatorname{Ltax}_{k}$ & 178.173 & 186.563 & 0.463734 & 213.535 & 0.347993 & 0.195313 \\
\hline Lfuel $_{k}$ & 465.242 & 470.298 & $386.45 \mathrm{I}$ & 484.403 & 0.184368 & 0.0396284 \\
\hline $\mathrm{Dat}_{k}$ & 0.835269 & 100.000 & 0.00000 & 100.000 & 0.370955 & 0.444114 \\
\hline Dath $_{k}$ & 0.0945796 & 0.00000 & 0.00000 & 100.000 & 0.292647 & 309.419 \\
\hline$D N_{k}$ & 0.589602 & 100.000 & 0.00000 & 100.000 & 0.491929 & $0.83434 I$ \\
\hline$D h a_{k}$ & 0.460177 & 0.00000 & 0.00000 & 100.000 & 0.498435 & 108.314 \\
\hline Dhst $_{k}$ & $0.609 \mid 45$ & 100.000 & 0.00000 & 100.000 & 0.487965 & 0.801065 \\
\hline Drye $_{k}$ & 0.833886 & 100.000 & 0.00000 & 100.000 & 0.372200 & 0.446343 \\
\hline$D t p a_{k}$ & 0.442478 & 0.00000 & 0.00000 & 100.000 & 0.496703 & 112.255 \\
\hline Variable & Skewness & Ex. kurtosis & Level (5.0 \%) & Level (95.0 \%) & IQ Score & Missing data \\
\hline$L x_{i k}$ & -0.617335 & 107.025 & 854.111 & 121.707 & $|45.04|$ & 0 \\
\hline$L x n_{k}$ & -127.129 & 225.353 & 101.999 & $14 \mid .859$ & 192.366 & 0 \\
\hline$L p_{i k}$ & -0.127936 & -0.753970 & -188.333 & 0.822681 & 126.826 & 0 \\
\hline$L t_{k}$ & 0.495672 & 0.520006 & 368.888 & 504.343 & 0.435318 & 0 \\
\hline$L c_{i k}$ & -111.962 & -0.210700 & 391.202 & 524.175 & 0.737110 & 0 \\
\hline$L q_{i k}$ & 0.58785 & 0.80284 & -0.66269 & 0.59007 & 0.91629 & 0 \\
\hline$L d_{k}$ & 0.375566 & 0.488665 & 454.329 & $685.96 \mathrm{I}$ & 0.519875 & 0 \\
\hline$L S M_{i k}$ & -131.649 & 293.380 & -142.712 & 0.00000 & 0.843970 & 0 \\
\hline $\operatorname{Liev}_{k}$ & -0.754561 & 157.344 & 430.767 & 467.243 & 0.141901 & 0 \\
\hline$L i p c_{k}$ & -0.409670 & -0.970217 & 460.419 & 465.541 & 0.0277418 & 0 \\
\hline$L_{i p h}$ & 0.00776093 & -0.465135 & 432.466 & 462.272 & 0.132163 & 0 \\
\hline $\operatorname{Lpob}_{k}$ & -0.532014 & -0.0796251 & 134.426 & 156.752 & 176.394 & 0 \\
\hline $\operatorname{Ltax}_{k}$ & -164.212 & 299.236 & 0.963174 & 213.535 & 0.355729 & 0 \\
\hline Lfuel $_{k}$ & $-258.74 I$ & 650.341 & 412.050 & 481.883 & 0.0983487 & 0 \\
\hline $\mathrm{Dat}_{k}$ & -180.769 & 126.773 & 0.00000 & 100.000 & 0.00000 & 0 \\
\hline Dath $_{k}$ & 277.084 & 567.756 & 0.00000 & 100.000 & 0.00000 & 0 \\
\hline$D N_{k}$ & -0.364304 & -186.728 & 0.00000 & 100.000 & 100.000 & 0 \\
\hline$D h a_{k}$ & 0.159800 & -197.446 & 0.00000 & 100.000 & 100.000 & 0 \\
\hline Dhst $_{k}$ & -0.447367 & -179.986 & 0.00000 & 100.000 & 100.000 & 0 \\
\hline Drye $_{k}$ & $-|79.42|$ & 121.918 & 0.00000 & 100.000 & 0.00000 & 0 \\
\hline$D_{t p a_{k}}$ & 0.231626 & -194.635 & 0.00000 & 100.000 & 100.000 & 0 \\
\hline
\end{tabular}

Revista de Evaluación de Programas y Políticas Públicas | Núm. 9 (2017), pp. 26-46 
Table 2. Routes of the Spanish market included in the sample (20II-20 I5).

\begin{tabular}{|c|c|c|c|c|c|}
\hline Origin & Destination & Airline & Origin & Destination & Airline \\
\hline A Coruña & Barcelona & VLG & Bilbao & Barcelona & VLG \\
\hline A Coruña & Madrid & IBE & Bilbao & Madrid & IBE \\
\hline Alicante & Barcelona & VLG & Bilbao & Madrid & UX \\
\hline Alicante & Madrid & IBE & Bilbao & Santiago & ANE \\
\hline Almería & Madrid & ANE & Bilbao & Valencia & ANE \\
\hline Asturias & Barcelona & VLG & Gran Canaria & Madrid & IBE \\
\hline Asturias & Madrid & IBE & Gran Canaria & Madrid & UX \\
\hline Barcelona & A Coruña & VLG & Granada & Madrid & $\mathrm{IBE}$ \\
\hline Barcelona & Alicante & VLG & Ibiza & Barcelona & FR \\
\hline Barcelona & Asturias & VLG & Ibiza & Barcelona & VLG \\
\hline Barcelona & Bilbao & VLG & Ibiza & Madrid & ANE \\
\hline Barcelona & Granada & VLG & Ibiza & Madrid & FR \\
\hline Barcelona & Ibiza & FR & Ibiza & Mallorca & ANE \\
\hline Barcelona & Ibiza & VLG & Ibiza & Valencia & ANE \\
\hline Barcelona & Madrid & IBE & Jerez & Madrid & IBE \\
\hline Barcelona & Madrid & UX & La Rioja & Madrid & ANE \\
\hline Barcelona & Madrid & VLG & Madrid & A Coruña & IBE \\
\hline Barcelona & Málaga & FR & Madrid & Alicante & IBE \\
\hline Barcelona & Málaga & VLG & Madrid & Almería & ANE \\
\hline Barcelona & Mallorca & FR & Madrid & Asturias & IBE \\
\hline Barcelona & Mallorca & UX & Madrid & Barcelona & IBE \\
\hline Barcelona & Mallorca & VLG & Madrid & Barcelona & UX \\
\hline Barcelona & Menorca & UX & Madrid & Barcelona & VLG \\
\hline Barcelona & Menorca & VLG & Madrid & Bilbao & IBE \\
\hline Barcelona & Santiago & FR & Madrid & Bilbao & UX \\
\hline Barcelona & Santiago & VLG & Madrid & Gran Canaria & IBE \\
\hline Barcelona & Sevilla & FR & Madrid & Gran Canaria & UX \\
\hline Barcelona & Sevilla & VLG & Madrid & Granada & IBE \\
\hline
\end{tabular}

Note: VLG, Vueling. IBE, Iberia. ANE, Air Nostrum. FR, Ryanair and UX, Air Europa. 
Table 2 (cont.). Routes of the Spanish market included in the sample (20II-20I5).

\begin{tabular}{|c|c|c|c|c|c|}
\hline Origin & Destination & Airline & Origin & Destination & Airline \\
\hline Madrid & Ibiza & FR & Melilla & Madrid & ANE \\
\hline Madrid & Jerez & IBE & Menorca & Barcelona & VLG \\
\hline Madrid & Málaga & IBE & Menorca & Madrid & ANE \\
\hline Madrid & Mallorca & FR & Menorca & Mallorca & ANE \\
\hline Madrid & Mallorca & IBE & Murcia & Madrid & ANE \\
\hline Madrid & Mallorca & UX & Pamplona & Madrid & IBE \\
\hline Madrid & Melilla & ANE & San Sebastián & Madrid & ANE \\
\hline Madrid & Menorca & UX & Santander & Madrid & ANE \\
\hline Madrid & Pamplona & ANE & Santander & Madrid & FR \\
\hline Madrid & San Sebastián & ANE & Santiago & Barcelona & FR \\
\hline Madrid & Santander & ANE & Santiago & Bilbao & ANE \\
\hline Madrid & Santander & FR & Santiago & Madrid & FR \\
\hline Madrid & Santiago & FR & Santiago & Madrid & IBE \\
\hline Madrid & Santiago & IBE & Sevilla & Alicante & ANE \\
\hline Madrid & Sevilla & ANE & Sevilla & Barcelona & FR \\
\hline Madrid & Tenerife Norte & IBE & Sevilla & Barcelona & VLG \\
\hline Madrid & Valencia & ANE & Sevilla & Gran Canaria & VLG \\
\hline Madrid & Vigo & IBE & Sevilla & Madrid & IBE \\
\hline Madrid & Vigo & UX & Sevilla & Valencia & ANE \\
\hline Málaga & Barcelona & FR & Tenerife Norte & Madrid & IBE \\
\hline Málaga & Barcelona & VLG & Tenerife Norte & Madrid & UX \\
\hline Málaga & Madrid & IBE & Valencia & Bilbao & ANE \\
\hline Mallorca & Barcelona & FR & Valencia & Ibiza & ANE \\
\hline Mallorca & Barcelona & UX & Valencia & Madrid & ANE \\
\hline Mallorca & Barcelona & VLG & Valencia & Málaga & ANE \\
\hline Mallorca & Ibiza & ANE & Valencia & Sevilla & ANE \\
\hline Mallorca & Madrid & FR & Vigo & Madrid & IBE \\
\hline Mallorca & Madrid & IBE & Vigo & Madrid & UX \\
\hline Mallorca & Menorca & ANE & & & \\
\hline
\end{tabular}

Note: VLG,Vueling. IBE, Iberia. ANE, Air Nostrum. FR, Ryanair and UX, Air Europa. 
Table 3. Demand Equation Results. Source: Own elaboration.

\begin{tabular}{|c|c|c|c|c|c|}
\hline \multicolumn{6}{|c|}{ Two-Stage Least Squares TSLS } \\
\hline \multicolumn{6}{|c|}{ Instrumental Variables: const Dath ${ }_{k}$ Dha $_{k}$ Dhst $_{k} L_{f u e}{ }_{k} L_{i p c_{k}}$} \\
\hline Equation I & Coef. & Coef.Value & std. error & z-stat & P-Value \\
\hline Const & $\delta 0$ & -6.45 & 1.75 & -3.69 & $0.0002 * * *$ \\
\hline $\operatorname{Liev}_{\mathrm{k}}$ & $\alpha 1$ & 3.66 & 0.39 & 9.27 & $1.83 \mathrm{e}-020 * * *$ \\
\hline$L q_{i k}$ & $\alpha 2$ & 2.13 & 0.19 & 11.12 & $9.75 \mathrm{e}-029 * * *$ \\
\hline$L p_{i k}$ & $\alpha 3$ & -0.60 & 0.06 & -8.70 & $3.2 \mathrm{le}-018 * * *$ \\
\hline$D N_{k}$ & $\alpha 4$ & 0.65 & 0.14 & 4.58 & $4.55 \mathrm{e}-06 * * *$ \\
\hline \multicolumn{6}{|c|}{ System of equations. Generalized method of moments (GMM) } \\
\hline \multicolumn{6}{|c|}{ 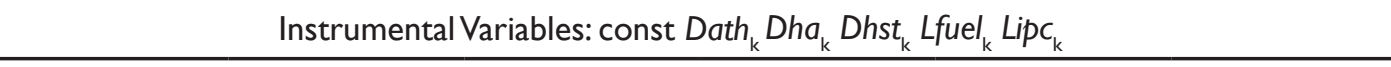 } \\
\hline Equation I & Coef. & Coef.Value & std. error & z-stat & P-Value \\
\hline Const & $\delta 0$ & -6.48 & 1.77 & -3.65 & $0.0003 * * *$ \\
\hline $\operatorname{Liev}_{\mathrm{k}}$ & $\alpha 1$ & 3.67 & 0.40 & 9.17 & $4.48 \mathrm{e}-020 * * *$ \\
\hline$L q_{i k}$ & $\alpha 2$ & 2.13 & 0.17 & 12.02 & $2.64 \mathrm{e}-033 * * *$ \\
\hline$L p_{\text {ik }}$ & $\alpha 3$ & -0.60 & 0.06 & -8.97 & $2.8 \mathrm{le}-019 * * *$ \\
\hline$D N_{k}$ & $\alpha 4$ & 0.64 & 0.13 & 4.85 & $1.18 \mathrm{e}-06 * * *$ \\
\hline
\end{tabular}

\begin{tabular}{|lrll|}
\hline \multicolumn{4}{c|}{ Two-Stage Least Squares TSLS } \\
\hline R-squared & 0.454584 & Adjusted R-squared & 0.454383 \\
Mean dependent var & 10.45137 & S.D. dependent var & 1.096588 \\
Sum squared resid & 10234.01 & S.E. of regression & 0.971512 \\
\hline
\end{tabular}

$(*): *$ indicates weak evidence ( $\mathrm{p}$ between 0.1 and 0.05 ), ${ }^{* *}$ indicates stronger evidence ( $\mathrm{p}$ between 0.05 and 0.01 ), and ${ }^{* * *}$ indicates very strong evidence ( $p$ smaller than 0.01 ).

\begin{tabular}{|c|c|c|c|c|}
\hline \multicolumn{5}{|c|}{ Weak instruments test } \\
\hline \multicolumn{5}{|c|}{ Cragg-Donald minimum eigenvalue $=|9.848|$} \\
\hline \multicolumn{5}{|c|}{ Critical values for TSLS bias relative to OLS: } \\
\hline bias & $5 \%$ & $10 \%$ & $20 \%$ & $30 \%$ \\
\hline value & 0.00 & 0.00 & 0.00 & 0.00 \\
\hline
\end{tabular}

Note: A value < 10 may indicate weak instruments (Stock and Yogo, 2005). 
Table 4. Market Share Equation Results. Source: Own elaboration.

\begin{tabular}{|c|c|c|c|c|c|}
\hline \multicolumn{6}{|c|}{ Two-Stage Least Squares TSLS } \\
\hline \multicolumn{6}{|c|}{ Instrumental Variables: const $L c_{\mathrm{ik}} L x n_{\mathrm{k}} L S M 1_{\mathrm{ik}} D t p a_{\mathrm{k}}$} \\
\hline Equation 2 & Coef. & Coef.Value & std. error & z-stat & P-Value \\
\hline Const & $\delta 0$ & -0.11 & 0.03 & -2.82 & $0.0047 * * *$ \\
\hline$L p_{i k}$ & $\beta 1$ & 0.20 & 0.03 & 5.59 & $0.0000 * * *$ \\
\hline$L q_{i k}$ & $\beta 2$ & -0.23 & 0.05 & -3.87 & $0.0001 * * *$ \\
\hline$D N_{k}$ & $\beta 3$ & -0.56 & 0.08 & -6.66 & $0.0000 * * *$ \\
\hline \multicolumn{6}{|c|}{ System of equations. Generalized method of moments (GMM) } \\
\hline \multicolumn{6}{|c|}{ Instrumental Variables: const $L c_{\mathrm{ik}} L x n_{\mathrm{k}} L S M 1_{\mathrm{iK}} D t p a_{\mathrm{k}}$} \\
\hline Equation 2 & Coef. & Coef.Value & std. error & z-stat & P-Value \\
\hline Const & $\delta 0$ & -0.11 & 0.03 & -3.15 & $0.0016 * * *$ \\
\hline$L p_{i k}$ & $\beta 1$ & 0.20 & 0.03 & 5.93 & $2.88 \mathrm{e}-09 * * *$ \\
\hline$L q_{i k}$ & $\beta 2$ & -0.23 & 0.05 & -4.11 & $3.95 \mathrm{e}-05 * * *$ \\
\hline$D N_{k}$ & $\beta 3$ & -0.56 & 0.07 & -7.50 & $6.23 \mathrm{e}-014$ *** \\
\hline
\end{tabular}

\begin{tabular}{|c|c|c|c|}
\hline \multicolumn{4}{|c|}{ Two-Stage Least Squares TSLS } \\
\hline R-squared & 0.416123 & Adjusted R-squared & $0.41596 \mid$ \\
\hline Mean dependent var & -0.518146 & S.D. dependent var & 0.546323 \\
\hline Sum squared resid & 1916.443 & S.E. of regression & 0.420391 \\
\hline
\end{tabular}

$(*)$ : indicates weak evidence ( $\mathrm{p}$ between 0.1 and 0.05 ), ${ }^{* *}$ indicates stronger evidence ( $\mathrm{p}$ between 0.05 and $0.0 \mathrm{I}$ ), and $* * *$ indicates very strong evidence ( $p$ smaller than 0.01 ).

\section{Weak instruments test}

Cragg-Donald minimum eigenvalue $=29.0831$

Critical values for TSLS bias relative to OLS:

\begin{tabular}{lcccc} 
bias & $5 \%$ & $10 \%$ & $20 \%$ & $30 \%$ \\
value & 0.00 & 0.00 & 0.00 & 0.00 \\
& Relative bias is probably less than $5 \%$ & \\
\hline
\end{tabular}

Note: A value $<10$ may indicate weak instruments (Stock and Yogo, 2005). 
Table 5. Price Equation Results. Source: Own elaboration.

\begin{tabular}{|c|c|c|c|c|c|}
\hline \multicolumn{6}{|c|}{ Two-Stage Least Squares TSLS } \\
\hline \multicolumn{6}{|c|}{ Instrumental Variables: const $\operatorname{Dtpa}_{\mathrm{k}} \operatorname{Dath}_{\mathrm{k}} \operatorname{Dat}_{\mathrm{k}} L_{\mathrm{L} o b_{\mathrm{k}}} \operatorname{Liph}_{\mathrm{k}}$} \\
\hline Equation 3 & Coef. & Coef.Value & std. error & z-stat & P-Value \\
\hline Const & $\delta 3$ & 3.76 & 0.64 & 5.87 & $4.13 \mathrm{e}-09 * * *$ \\
\hline$L d_{k}$ & $\theta 2$ & -0.09 & 0.05 & -1.78 & $0.0745 *$ \\
\hline$L c_{i k}$ & $\theta 3$ & -0.63 & 0.10 & -6.19 & $5.74 \mathrm{e}-10 * * *$ \\
\hline$D N_{k}$ & $\theta 3$ & -1.13 & 0.10 & -11.34 & $8.37 \mathrm{e}-030 * * *$ \\
\hline$L q_{i k}$ & $\theta 4$ & -0.38 & 0.14 & -2.67 & $0.0075 * * *$ \\
\hline \multicolumn{6}{|c|}{ System of equations. Generalized method of moments (GMM) } \\
\hline \multicolumn{6}{|c|}{ Instrumental Variables: const $\operatorname{Dtpa}_{\mathrm{k}} \operatorname{Dath}_{\mathrm{k}} \operatorname{Dat}_{\mathrm{k}} \operatorname{Lpob}_{\mathrm{k}} \mathrm{Liph}_{\mathrm{k}}$} \\
\hline Equation 3 & Coef. & Coef.Value & std. error & z-stat & P-Value \\
\hline Const & $\delta 3$ & 3.70 & 0.61 & 6.06 & $1.33 \mathrm{e}-09 * * *$ \\
\hline$L d_{k}$ & $\theta 2$ & 0.09 & 0.05 & -1.83 & $0.0667 *$ \\
\hline$L c_{i k}$ & $\theta 3$ & -0.63 & 0.10 & -6.19 & $5.89 \mathrm{e}-010 * * *$ \\
\hline$D N_{k}$ & $\theta 3$ & -1.15 & 0.09 & -12.32 & $6.74 \mathrm{e}-035 * * *$ \\
\hline$L q_{\text {ik }}$ & $\theta 4$ & -0.39 & 0.13 & -2.85 & $0.0043 * * *$ \\
\hline
\end{tabular}

\begin{tabular}{|lrll|}
\hline \multicolumn{4}{c|}{ Two-Stage Least Squares TSLS } \\
\hline R-squared & $0.28821 I$ & Adjusted R-squared & 0.287949 \\
Mean dependent var & -0.512544 & S.D. dependent var & 0.818686 \\
Sum squared resid & 6514.746 & S.E. of regression & 0.775129 \\
\hline
\end{tabular}

$(*): *$ indicates weak evidence ( $\mathrm{p}$ between $0 . \mathrm{I}$ and 0.05$)$, ${ }^{* *}$ indicates stronger evidence ( $\mathrm{p}$ between 0.05 and $0.0 \mathrm{I}$ ), and $* * *$ indicates very strong evidence ( $p$ smaller than 0.01 ).

\section{Weak instruments test}

Cragg-Donald minimum eigenvalue $=20.3802$

Critical values for TSLS bias relative to OLS:

$\begin{array}{lllll}\text { bias } & 5 \% & 10 \% & 20 \% & 30 \% \\ \text { value } & 0.00 & 0.00 & 0.00 & 0.00\end{array}$

Relative bias is probably less than $5 \%$

Note: A value < 10 may indicate weak instruments (Stock and Yogo, 2005). 
Table 6. Entropy, Herfindahl and Lerner Index (20I4). Source: Own elaboration.

\begin{tabular}{lccccc}
\hline & TOTAL & SHARE (\%) & $\begin{array}{c}\text { ENTROPY } \\
\text { INDEX }\end{array}$ & $\begin{array}{c}\text { HERFINDAL } \\
\text { INDEX }\end{array}$ & $\begin{array}{c}\text { LERNER } \\
\text { INDEX }\end{array}$ \\
\hline Vueling & $15,104,393$ & 29.54 & 0.16 & 0.09 & 0.17 \\
Ryanair & $9,918,910$ & 19.36 & 0.14 & 0.04 & 0.07 \\
Iberia + IB Express & $9,871,562$ & 19.27 & 0.14 & 0.04 & 0.07 \\
Air Europa & $9,089,176$ & 17.74 & 0.13 & 0.03 & 0.06 \\
Air Nostrum & $5,219,415$ & 10.19 & 0.10 & 0.01 & 0.02 \\
Air Berlin & $1,930,997$ & 3.77 & 0.05 & 0.00 & 0.00 \\
Others & 92,21 & 0.18 & 0.00 & 0.00 & 0.00 \\
\multicolumn{1}{c}{ TOTAL } & $\mathbf{5 1 , 2 2 6 , 6 6 3}$ & $\mathbf{1 0 0}$ & $\mathbf{0 . 7 3}$ & $\mathbf{0 . 2 1}$ & $\mathbf{0 . 4 1}$ \\
\hline \hline
\end{tabular}

